\title{
SHORT GLOSSARY OF CRITICAL AND LITERARY TERMS
}

Aleatory: the intrusion of the random into life; the messiness of existence, refuting claims that the world is ordered.

Atavism: regression back to a primitive state; the erasure of civilisation.

Cubism: the radical rejection of Renaissance notions of perspective and ordered space; a flattening of the subject so that different sides, angles and views can be perceived simultaneously. Turns space into a multitude of flat, depthless, plates.

Deconstruction: a breaking up of language into codes and systems, thereby revealing the institutionalised systems of power which underpin all signs and forms of knowledge.

Futurism: an attempt to represent movement, speed and noise; a crypto-fascist obsession with machine-made power, energy and dynamism.

Intertextuality: texts which reference other texts in an explicit manner; the relationship between books.

Local Colour: generally understood in terms of a tendency in nineteenth-century American literature to lionise idiosyncratic customs and manners as a kind of literary tourism. The term usually suggests a genteel obsession with quaint local peculiarities, and thus is much more sentimental than Regionalism, depending upon an old-fashioned, nostalgic faith in 'plain folks' and traditional ways of life.

Metafiction: fiction which draws attention to its own fictional state. A puncturing of the mimetic illusion.

Mimesis: Greek for 'imitation'. A mimetic piece of writing is founded upon a belief in a genuine reproduction of external reality. 
Modernism: in literary or artistic terms, the revolutionary explosion of experimental art in the first half of the twentieth century, overturning previous aesthetic practices and conventions (including that of orthodox 'realism'). 'To be modern is to experience life as a maelstrom, to find one's world and one's self in perpetual ambiguity and contradiction' (Marshall Berman). Key terms are agitation, dizziness, drunkenness, chaos, speed and disintegration. Also seen as an aesthetic response to the machine age, urbanisation and the dawn of the mass media.

Naturalism: a literary movement (chiefly understood in terms of the mid to late nineteenth-century) which aimed to bring a pseudo-scientific objectivity to the art of fiction. Drawing upon post-Darwinian biology, it argued the case for a deterministic universe, wherein free-will is seen as considerably weaker than the brutal forces of heredity and one's environment. Although intended to be free from any distortion or authorial bias, naturalistic writing is frequently pessimistic, exaggerated and grotesque, exploring the seamier areas of perversion and violence. It is therefore linked at times with Expressionism, wherein reality is malformed by extreme mental and emotional states. Whilst the scientific trappings of the term have fallen away, a Naturalistic tendency can be traced throughout twentieth-century fiction.

Nihilism: the rejection of any kind of essential morality or meaning.

Numinous: supernatural, mysterious, ineffable; what cannot be put into words.

Pastiche: a knowing imitation of a pre-existing style, which doesn't parody or satirise the original, but merely repeats it in a deadpan manner.

Postmodernism:'Postmodernism is what you have when the modernization process is complete and nature is gone for good' (Fredric Jameson). The triumph of the artificial and the end of the natural, original or authentic. An age in which reproduction overtakes production. Key terms are blankness, kitsch, repetition, and simulation. Also seen as an aesthetic response (and/or symptom) of the late-capitalist era of information overload and mass consumerism.

Post-Structuralism: philosophy which states that all linguistic meaning is a result of the relationship between signs, rather than between signs and the real world (the signified). 
Quotidian: the everyday; in literary terms, what is often left out of realistic fiction (having to go to the toilet, getting stuck in traffic etc.) unless it is relevant to the plot.

Realism: on the surface this appears the most straightforward of literary terms, denoting the accurate reportage of the real world or actual life. Its virtues are honesty, exactness, sobriety and truth. The problem, of course, is that it presupposes an agreed-upon notion of reality - and therein lies the source of enormous theoretical difficulty. What might be to some self-evident common-sense, will be to others wholly false and dishonest; whether a thing is 'realistic' or not depends on shared assumptions and beliefs. In literary terms, realism suggests less an unproblematic reflection of the world than a mutual, communicable system of conventions; to some critics, verisimilitude (the appearance of being real) denotes a commitment to unadorned existential truth, whilst to others it is a mendacious illusion intended to convince the reader of the supposedly objective nature of the author's personal bias.

Regionalism: an emphasis upon specific geographical settings, via history, customs, dialect, manners and so on. The interests of regionalism are frequently sociological or even anthropological, and for many critics the term has rather negative connotations, suggesting something parochial, insular and small-minded, at least when compared with the great universal themes of High Art. Postmodernist thinking, which doesn't believe in such timeless universal definitions, has rekindled an interest in marginal or peripheral zones of experience, but is in turn suspicious of regionalism's links with what it sees as a discredited realism. Despite this, regionalism has achieved a new prominence in terms of an imaginative resistance to the standardising influence of global consumerism and homogeneous market-forces.

Romance: as an (extremely broad) genre, the romance denotes the creation of an imaginatively autonomous fictive world. Rather than transcribing reality, it uses events, characters and settings as allegorical symbols for abstract, spiritual properties, especially to do with the soul.

Self-reflexive: something that refers back to itself; self-reflective or self-validating.

Simulacrum: the identical copy of something for which no original has ever existed; a copy of a copy of a copy, until the prototype somehow 
disappers. Used as a description of the flow of images within the mass-media.

Solipsism: the philosophy that one can know nothing outside of one's own experience.

Sublime: awe-inspiring, elevated, beyond any means of description or any human scale.

Surrealism: an attempt to liberate the imagination from the constraints of reason or order via dreams, visions, hallucinations and madness.

Transcendentalism: a nineteenth-century philosophical tendency, which expresses a profoundly individualistic form of religious belief. Nature, rather than the church, acts as one's conduit to higher spiritual truth, the landscape a series of divine hieroglyphics intuitively translated by the imagination. 